Louisiana State University

LSU Digital Commons

Faculty Publications

Department of Oceanography \& Coastal

Sciences

6-5-2010

\title{
Abundance And Ecological Significance Of The Clam Rangia \\ Cuneata (Sowerby, 1831) In The Upper Barataria Estuary (Louisiana, USA)
}

Wai Hing Wong

Nancy N. Rabalais

nrabalais@lumcon.edu

R. Eugene Turner

euturne@lsu.edu

Follow this and additional works at: https://digitalcommons.Isu.edu/oceanography_coastal_pubs

Digitart of the Oceanography Commons

Commons

Network

Recommended Citation

Wơng, W. H., Rabalais, N. N., \& Turner, R. (2010). Abundance And Ecological Significance Of The Clam

Rangia Cuneata (Sowerby, 1831) In The Upper Barataria Estuary (Louisiana, USA). https://doi.org/

10.1007/s10750-010-0310-z

This Article is brought to you for free and open access by the Department of Oceanography \& Coastal Sciences at LSU Digital Commons. It has been accepted for inclusion in Faculty Publications by an authorized administrator of LSU Digital Commons. For more information, please contact ir@lsu.edu. 


\title{
Abundance and ecological significance of the clam Rangia cuneata (Sowerby, 1831) in the upper Barataria Estuary (Louisiana, USA)
}

\author{
Wai Hing Wong • Nancy N. Rabalais • \\ R. Eugene Turner
}

Received: 2 February 2010/Revised: 4 May 2010/Accepted: 17 May 2010/Published online: 4 June 2010

(C) Springer Science+Business Media B.V. 2010

\begin{abstract}
We proposed that Rangia cuneata (Sowerby, 1831) is an important estuarine bivalve with ecological significance in three coastal lakes in Barataria Bay, Gulf of Mexico-Lake Cataouatche, Lake Salvador and Lac des Allemands. Our goals were to determine the abundance and distribution of Rangia in these lakes and to measure clearance times to elucidate its potential impacts on phytoplankton communities. The estimated average densities of $R$. cuneata in Lake Cataouatche, Lake Salvador, and Lac des Allemands were 63, 157, and 107 individuals $\mathrm{m}^{-2}$, respectively, which is $30 \%$ lower than that observed in nearby Lake Pontchartrain. The size of
\end{abstract}

Handling editor: P. Viaroli

W. H. Wong $(\bowtie)$

Department of Environmental and Occupational Health, University of Nevada, Las Vegas, 4505 Maryland

Parkway, Box 452040, Las Vegas, NV 89154,

USA

e-mail: david.wong@unlv.edu

\section{N. N. Rabalais}

Louisiana Universities Marine Consortium, 8124 Highway 56, Chauvin, LA 70344, USA

e-mail: NRabalais@lumcon.edu

\section{R. E. Turner}

Department of Oceanography and Coastal Sciences, Louisiana State University, Energy, Coast and Environment Building, Baton Rouge, LA 70803,

USA

e-mail: euturne@1su.edu clams in Lake Salvador was between 4 and $50 \mathrm{~mm}$, while individuals in Lake Cataouatche and Lac des Allemands were mostly $>20 \mathrm{~mm}$. We postulate that a relatively infrequent large tropical storm transported the larvae from Lake Salvador to the other two lakes 1 year before our sampling to create this size difference. The clams were up to $99.9 \%$ of the total benthic biomass in Lake Salvador, $15.9 \%$ in Lake Cataouatche, and $40.0 \%$ in Lac des Allemands. The $R$. cuneata biomass values were between 16.2 and $27.6 \mathrm{~g} \mathrm{~m}^{-2}$ and the clearance times were 1.0 1.5 days. The clearance times are among the highest previously reported for coastal bivalve communities, which were from cooler climates. The results demonstrate that Rangia can be a critical part of the ecological processes in shallow water systems of the Gulf of Mexico.

Keywords Rangia cuneata - Clams · Abundance $\cdot$ Clearance rate $\cdot$ Comparisons . Louisiana

\section{Introduction}

Bivalves can be quantitatively significant components of estuarine ecosystems as prey, habitat structure for other organisms, and as biochemical agents influencing nutrient cycles. In the process of feeding by filtration, oysters, mussels, and clams may significantly reduce particle concentrations in some systems 
(Cohen et al., 1984; Cloern \& Alpine, 1991; Caraco et al., 1997; Haamer \& Rodhe, 2000), but not in others (Ball et al. 1997; Pomeroy et al. 2006, 2007). Officer et al. (1982) outlined the critical convergence of factors necessary for benthic community control of phytoplankton: "for shallow water depths a benthic community of a few hundred $\mathrm{g} \mathrm{m}^{-2}$ will act as a control on the phytoplankton population, and the plankton concentrations will be a few $\mu$ g chlorophyll $1^{-1}$." Shallow water depths and high bivalve biomass will, therefore, result in relatively lower 'clearance time(s)' (CT), defined as the amount of time (days) that it takes to filter the water above the bivalve community. Water residence time, however, is inversely related to the influences of bivalve filtration on standing stocks, because of the reduction in contact time.

The Gulf of Mexico (GOM) estuaries are likely locations where the bivalve CT may be low enough to have an influence on the planktonic community because: (1) the average time to replace estuarine volume with its freshwater inflow for the $30 \mathrm{GOM}$ estuaries is relatively slow (184 days), (2) the average depth is shallow $(2.5 \pm 1.5 \mathrm{~m})$, and (3) tides are microtidal (less than $1 \mathrm{~m}$; Turner, 2001). Under these conditions, it is possible that the benthic community can interact with the overlying water to significantly affect the net phytoplankton accumulation. We know of no estimate of CT for bivalves in the GOM, or anywhere south of South Carolina (lat. $33^{\circ} 20^{\prime} 58^{\prime \prime}$; Dame \& Prins, 1998).

A dominant bivalve of the GOM estuaries is $R$. cuneata (Sowerby, 1831), known as the Atlantic Rangia, Rangia clam, brackish water clam, or estuarine clam. This clam was absent on the east coast since the Pleistocene until it re-appeared as far north as New York in the last century (Hopkins \& Andrews, 1970). It was recently reported to have invaded Belgium (Verween et al., 2006). It is comprises as much as $95 \%$ of the total benthic biomass in the GOM (Lasalle \& De La Cruz, 1985) and occurs in a high enough abundance to be a significant prey for crab, fish, shrimp, and waterfowl (Cain, 1975; LaSalle \& de la Cruz, 1985; Ebersole \& Kennedy, 1994) and is a notable substratum for epifauna (Hoese, 1973). Rangia are non-selective filter feeders (Gaston et al., 1997) that are harvested by local fishing communities of the coastal GOM (Andrews \& Grodner, 1995; Wakida-Kusuoki \&
MacKenzie, 2004). The shells of $R$. cuneata in Lake Pontchartrain, a large estuarine system in southeastern Louisiana, supported a dredging industry from 1933 to 1990 . Dredging reduced sediment stability and the size of live Rangia (Sikora \& Sikora, 1981). The size and number of Rangia in the lake increased and the water became clearer after clam dredging ceased (Francis \& Poirrier, 1999; Abadie \& Poirrier, 2000). The invasion of the Asiatic clam in the Potomic River in the 1980s led to increased water clarity, then higher submerged aquatic vegetation (SAV), and then waterfowl and fisheries populations (Phelps, 1994). These results, and others, imply that Officer et al.'s hypotheses about the role of bivalves in controlling phytoplankton communities is of significance to the management of water quality in GOM coastal waters.

The objectives of this study in the upper Barataria Bay, Louisiana, were to determine Rangia abundance and distribution, and the allometric relationships between shell length and tissue/shell weight necessary to estimate the CT of Rangia. We use these results on biomass and CT to make comparisons with other systems.

\section{Materials and methods}

\section{Area description}

Field work was conducted in three lakes of the upper Barataria Basin, southeastern Louisiana: Lake Cataouatche, Lake Salvador, and Lac des Allemands (Fig. 1) during May and June 2004. The Barataria Basin, bordered on the east by the Mississippi River (Fig. 1), receives most of its fresh water from rainfall that either reaches the basin's waters directly or arrives via land runoff. The water quality in the watershed ranges from oligotrophic to hypereutrophic and eutrophication has increased dramatically from the mid-1960s to the mid-1970s as nutrient loads from riverine and local sources increased (Rabalais, 2005).

The depths of these lakes are between 2 and $3 \mathrm{~m}$. We used the topographic maps to determine the area of each lake, and the average depth from nautical charts to determine that the water volume is $7.45-7.67 \times 10^{7} \mathrm{~m}^{3}$ in Lake Cataouatche, $4.8-4.9 \times 10^{8} \mathrm{~m}^{3}$ in Lake Salvador, and $1.3 \times 10^{8} \mathrm{~m}^{3}$ in Lac des Allemands. The salinity of all three lakes is $<1$ psu (Table 1 ). 
Fig. 1 Location map (clam and sediment sampling locations are labeled with open and closed circles, respectively)
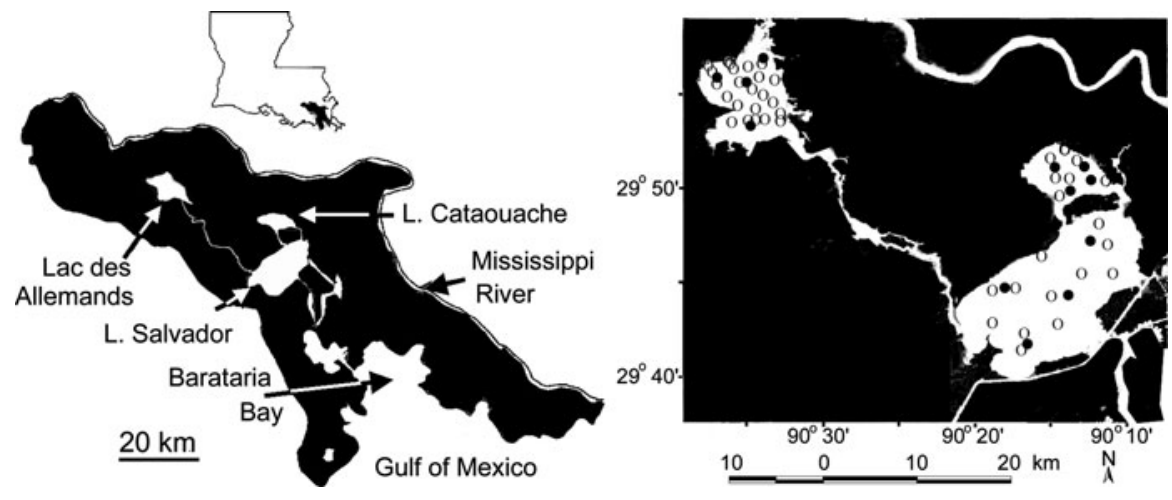

The slightly brackish waters of Lakes Salvador and Cataouatche are influenced by the microtidal exchange $(<20 \mathrm{~cm})$ from the lower Barataria Basin and the Gulf of Mexico. Lake Cataouatche recently became even fresher because of a Mississippi River diversion at Davis Pond, part of the Louisiana Coastal Area Ecosystem Restoration Study (Rabalais, 2005). Lac des Allemands drains into Lake Salvador through a narrow channel, Bayou Lac des Allemands, and Lake Salvador and Lake Cataouatche are connected to each other by two short channels (Fig. 1). A comparison of the water temperature, dissolved oxygen, Chlorophyll $a$ concentration, and salinity in the three lakes between fall 2003 and summer 2004 is in Table 1. The major difference among the three lakes is that Lac des Allemands is largely more eutrophic than the other two lakes.

Sample collection and analysis

Sediment samples from four locations were collected from each lake using an Eckman Grab. The sediment grain size was classified into three major groups: sand $(>63 \mu \mathrm{m})$, silt $(4-63 \mu \mathrm{m})$, and clay $(<4 \mu \mathrm{m})$ (Krumbein \& Pettijohn, 1938). Sediment penetrability was quantified in the locations where macrobenthic samples were collected using a plastic penetrometer
(4.50 $\mathrm{M}$ long and $20 \mathrm{~cm}$ diameter). The penetrometer was dropped into the sediment surface and the maximum penetrated depth recorded (Kelaher et al., 2003).

Two replicate sediment samples were taken with a Ponar grab $\left(0.025 \mathrm{~m}^{2}\right)$ at each of 7 locations in Lake Cataouatche, 12 locations in Lake Salvador, and 25 locations in Lac des Allemands (Fig. 1). The sampling density was $5.4,15$, and 2.4 samples $\mathrm{km}^{-2}$ in Lake Cataouatche, Lake Salvador, and Lac des Allemands, respectively, which compares to the Rangia sampling density conducted by Abadie \& Poirrier (2000) and using the same equipment, of 37, 146, and 39 samples $\mathrm{km}^{-2}$ for nearby Lakes Pontchartrain, Borgne, and Maurepas, respectively. The material from one replicate not passing through a 500- $\mu \mathrm{m}$ mesh sieve was put into glass containers and preserved with 5\% neutral-buffered formalin until further assemblage analysis. All of the macroinvertebrates were identified under a dissecting microscope, counted, dried in an oven at $60^{\circ} \mathrm{C}$ for $24 \mathrm{~h}$, and weighed to the nearest $0.0001 \mathrm{~g}$. The length of all live and dead clam shells was measured to the nearest $0.01 \mathrm{~mm}$ using digital calipers (Mitutoyo Corp., Aurora IL, USA). These clams were dried at $60^{\circ} \mathrm{C}$ for $24 \mathrm{~h}$, and the dry tissue and dry shells of each clam weighed. The material in the second replicate

Table 1 Water characteristics of the three study lakes from fall 2003 to summer 2004 ( $\mu \pm 1$ SE)

\begin{tabular}{lccc}
\hline & Lake Cataouatche & Lake Salvador & Lac des Allemands \\
\hline Temperature $\left({ }^{\circ} \mathrm{C}\right)$ & $22.74 \pm 3.94$ & $22.24 \pm 3.62$ & $21.10 \pm 3.62$ \\
DO $\left(\mathrm{mg} \mathrm{l}^{-1}\right)$ & $10.21 \pm 1.52$ & $9.68 \pm 0.71$ & $9.25 \pm 1.02$ \\
Salinity $(\mathrm{psu})$ & $0.39 \pm 0.12$ & $0.37 \pm 0.13$ & $0.12 \pm 0.03$ \\
Chlorophyll $a\left(\mu \mathrm{g} \mathrm{l}^{-1}\right)$ & $17.63 \pm 9.94$ & $10.54 \pm 4.65$ & $61.77 \pm 41.11$ \\
Freshwater residence time (days) & 20.9 & 19.2 & 209 \\
\hline
\end{tabular}


was used to evaluate the tissue-shell length relationship and condition index (CI) of living clams, defined as dry tissue mass (mg)/dry shell mass (g) (Kang et al., 2000). These data were used to derive the relationship between clam tissue weight and shell length, and the relationship between living shell weight and shell length.

The filtration rates of clams collected from Lake Salvador and Lac des Allemands in July 2004 were estimated by conducting feeding experiments. About 50 clams were collected from each lake and transported to the lab in 5-1 plastic containers filled with water and equipped with a cooler to maintain the in situ temperature. These clams were transferred at the laboratory into eight buckets, each with 101 of lake water that was oxygenated with an air stone. The clams were acclimated in this container for $6 \mathrm{~h}$ and then healthy and actively feeding clams (based on the observation on their siphons) were selected and for the feeding experiments. There were four clams in each of four buckets, and four buckets without clams used as control. The clam filtration rate (FR) over $1 \mathrm{~h}$ was based on the reduction of Chl- $a$ concentration (Coughlan, 1969):

$\mathrm{FR}=\mathrm{V} \times\left(\left(\ln C_{0}-C_{t}\right)-\left(\ln C_{0}^{\prime}-C_{t}^{\prime}\right)\right) / t$

where FR is the filtration rate in 1 hour $^{-1}, V$ is the volume $(101)$ of lake water, $C_{0}$ is the initial Chl- $a$ concentration $\left(\mu \mathrm{g} \mathrm{l}^{-1}\right)$ in the bucket with clams, $\mathrm{C}_{\mathrm{t}}$ is the Chl- $a$ concentration $\left(\mu \mathrm{g}^{-1}\right)$ in the bucket with clams at time $t, C_{0}{ }^{\prime}$ is the initial Chl- $a$ concentration $\left(\mu \mathrm{g} 1^{-1}\right.$ ) in the control bucket, $C_{t}^{\prime}$ is the Chl- $a$ concentration $\left(\mu \mathrm{g} \mathrm{l}^{-1}\right)$ in the control bucket at time $t$ (hours), and $t=1 \mathrm{~h}$. At the end of the experiment, the clams from each bucket were dissected to obtain the dry weight as described above.

\section{Data analysis}

We conducted an analysis of variance (ANOVA) to compare the clam density and CI of clams among the three lakes. Linear and non-linear regression analyses were used to investigate the relationship(s) between shell length and both dry weight and body tissue weight. The shell length and weight data were log transformed to facilitate the comparison between live and dead shells, and the slope and intercept were compared (Zar, 1996). A $t$ test was used to detect if there were any significant differences in the filtration rates of clams between Lake Salvador and Lac des Allemands. The level of significance was $\alpha=0.05$.

\section{Results}

Lake sediments

The sediment of the three lakes (Fig. 2) was mainly composed of clay $(<4 \mu \mathrm{m})$, which was $94 \%$ in Lac des Allemands, $89 \%$ in Lake Cataouatche, and $75 \%$ in Lake Salvador. The sand content was $24 \%$ in Lake Salvador, $11 \%$ in Lake Cataouache, and $3 \%$ in Lac des Allemands.

Clam abundance, size and condition index

The clam density (individuals $\mathrm{m}^{-2}$ ) was highest in Lake Salvador $\left(156.7 \pm 36.7 \mathrm{~m}^{-2}\right)$ and lowest in Lake Cataouatche $\left(62.9 \pm 37.9 \mathrm{~m}^{-2}\right.$; Table 2). There were, however, no significant differences in clam density among the three lakes $(P>0.05)$ because of the high sample variation within each lake. The accumulated shell mass in Lake Salvador was $7010 \mathrm{~g} \mathrm{~m}^{-2}$, which was about 100 times greater than that in Lake Cataouatche $\left(79 \mathrm{~g} \mathrm{~m}^{-2}\right)$ and in Lac des Allemands (62 $\mathrm{g} \mathrm{m}^{-2}$; Table 2). The size frequency distributions of clam shells in each lake were different from each other (Fig. 3). In Lake Salvador, there were peaks at $5 \mathrm{~mm}(12 \%$ of the total) and $30 \mathrm{~mm}$ (equal to $16 \%$ of the total), while there was only one peak (at $38 \mathrm{~mm}$, equal to $40 \%$ of the total)

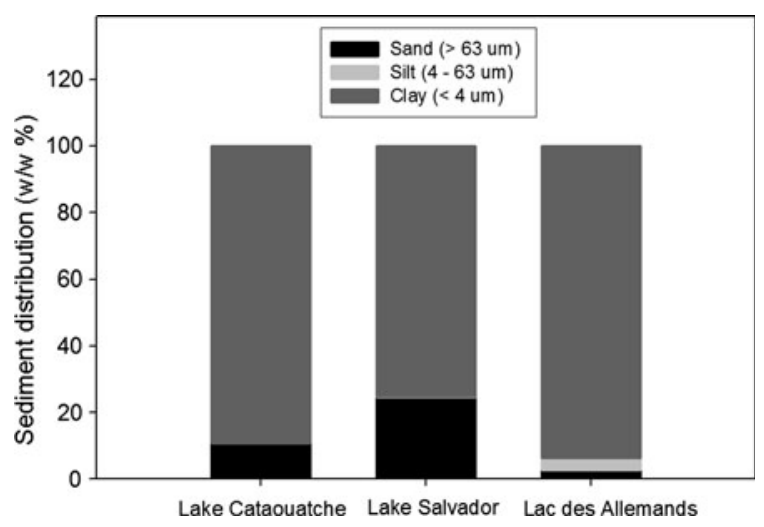

Fig. 2 Sediment grain size distribution in the three lakes 
in Lake Cataouatche and one peak in Lac des Allemands (at $32 \mathrm{~mm}$, equal to $33 \%$ of the total).

The CI of clams in Lake Cataouatche, Lake Salvador, and Lac des Allemands was 6.3, 4.3, and 3.3 , respectively (Table 2). There was no significant difference among sites (ANOVA, $P>0.05$ ) because of the high variation among different locations within each lake, and especially in Lake Cataouatche. The CI of clams in these three lakes are intermediate to the CI values that Peddicord (1977) describe for the James River estuary, Virginia (1.4-11.3).

The clams were up to $99.9 \%$ of the total benthic biomass in Lake Salvador, $15.9 \%$ in Lake Cataouatche, and 40.0\% in Lac des Allemands (Fig. 4). In Lac des Allemands, the oligochaetes had the highest benthic biomass $(50.3 \%)$ and chironomids were also abundant. In Lake Cataouatche, the oligochaetes also had highest biomass $(61.8 \%)$ followed by gastropods $(18.3 \%)$.

\section{Clam distribution}

Compared to the other two lakes, clams were more abundant and distributed more evenly in Lake Salvador which has sandier sediments (Fig. 2). Although clams were found at every sampling site in Lake Salvador, there were no clams in some locations in the other two lakes. The density of $R$. cuneata was always low where the sediment was relatively soft (i.e., higher sediment penetrability), while the density of clams was relatively high or low where the sediment penetrability was low (Fig. 5).

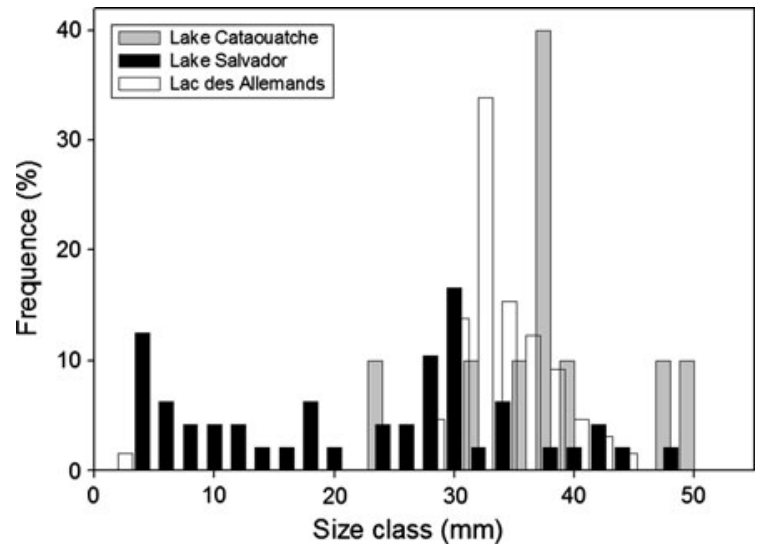

Fig. 3 The size frequency of Rangia in the three coastal lakes

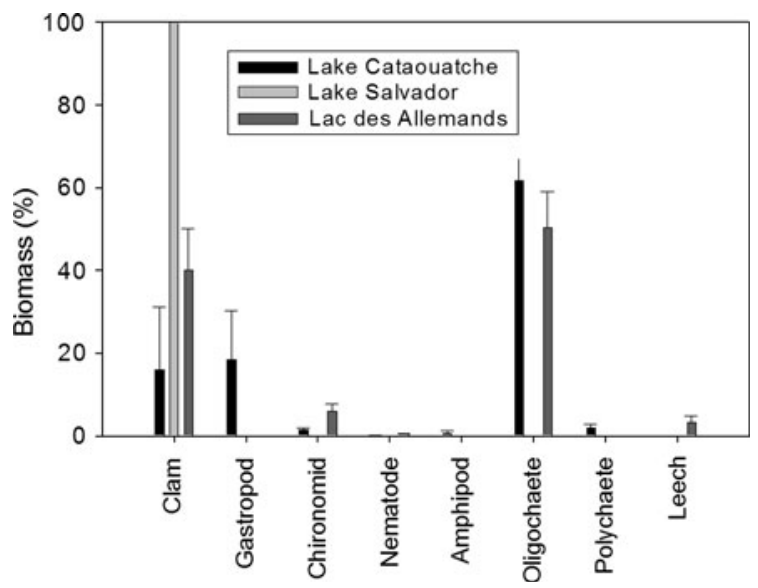

Fig. 4 The biomass of Rangia clams and other benthic macrofauna in the three coastal lakes

Table 2 Clam density, shell mass, clam body condition index, biomass, and clearance time for the three study lakes ( $\mu \pm 1$ SE)

\begin{tabular}{llll}
\hline & Lake Cataouatche & Lake Salvador & Lac des Allemands \\
\hline Density all shells (individual $\mathrm{m}^{-2}$ ) & $62.9 \pm 37.9$ & $156.7 \pm 36.7$ & $107.2 \pm 33.8$ \\
& $(N=7)$ & $(N=12)$ & $(N=25)$ \\
Density shells $>20 \mathrm{~mm}^{-2}$ individual $\left.\mathrm{m}^{-2}\right)$ & 57.2 & 56.7 & 107.2 \\
Empty shell mass $\left(\mathrm{g} \mathrm{m}^{-2}\right)$ & $78.6 \pm 29.4 \mathrm{a}$ & $7010.3 \pm 1587.5 \mathrm{~b}$ & $62.4 \pm 60.2 \mathrm{a}$ \\
& $(N=5)$ & $(N=10)$ & $(N=5)$ \\
Condition index & $6.32 \pm 1.30$ & $4.33 \pm 0.52$ & $3.25 \pm 0.14$ \\
& $(N=3)$ & $(N=34)$ & $(N=18)$ \\
Biomass $\left(\mathrm{g} \mathrm{m}^{-2}\right)$ & 16.2 & 15.1 & 27.6 \\
& $(N=7)$ & $(N=12)$ & $(N=25)$ \\
Clearance time (days) & 1.5 & 1.5 & 1.0 \\
\hline
\end{tabular}

Note: Different letters denote significant difference among the three lakes (ANOVA, $P<0.05$ ) 
Almost no clams were found where the sediment penetration index was deeper than $0.8 \mathrm{~m}$ (Fig. 5).

\section{Allometric relationships}

The relationship between tissue dry weight $(\mathrm{mg})$ and shell length $(\mathrm{mm})$ can be described by a power function, where:

Tissue dry weight $=0.0047 \times(\text { shell length })^{3.00}$,

$$
R^{2}=0.95, N=60
$$

The relationship between the dry shell weight of live shells $(\mathrm{mg})$ and shell length $(\mathrm{mm})$ is described by a power function, where:

$$
\begin{aligned}
\text { Dry weight } & =0.060 \times \text { length }^{3.46}, \\
R^{2} & =0.99, N=223
\end{aligned}
$$

The relationship between the dry shell weight (mg) of dead shells and shell length $(\mathrm{mm})$ is described by a power function, where:

$$
\begin{aligned}
\text { Dry weight } & =0.036 \times \text { length }^{3.57}, \\
R^{2} & =0.99, N=291
\end{aligned}
$$

After the data were log-transformed, the two linear regression were significantly different in slopes $(t=2.82, \quad P<0.05)$ and intercepts $(t=5.86$, $P<0.01)$. The living shell, therefore, was heavier than the dead shell at the same shell length.

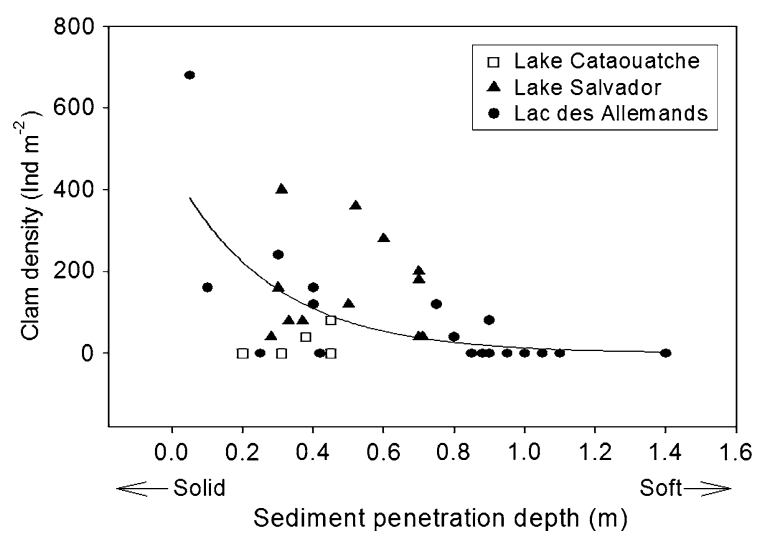

Fig. 5 The relationship between sediment penertration and clam density. The equation fitting the data is: clam den-

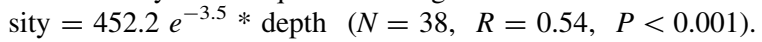
Dark triangle Lake Salvador; White square Lake Cataouatche, Dark Circle Lac des Allemands
Clam biomass

We used the allometric relationships between shell length and tissue weight, and the density and length frequency of these clams in each lake, to estimate the biomass of this clam in Lakes Cataouatche and Salvador, and in Lac des Allemands, which was $16.2 \mathrm{~g}, 15.1 \mathrm{~g}$, and $27.6 \mathrm{~g} \mathrm{~m}^{-2}$, respectively (Table 2). The lower tissue biomass in Lake Salvador and high density (Table 2) demonstrates that the size of individual clams in Lake Salvador was smaller than those in other two lakes (Fig. 2).

\section{Clearance times}

The dry weight of the four experimental clams used in each of the buckets for Lake Salvador and Lac des Allemands varied from 0.62 to $0.80 \mathrm{~g}$ and from 0.71 to $0.94 \mathrm{~g}$, respectively. There was no significant difference in the biomass of four experimental clams in each bucket between the two lakes ( $t$ test, $P>0.05)$. The filtration rates of the clams in Lake Salvador and Lac des Allemands were 1.35 and $2.27 \mathrm{~h} \mathrm{~h}^{-1}$, respectively, but no significant difference in the FR was detected between these two lakes either ( $t$ test, $P>0.05$ ). Based on the relationship between clam size and filtration rate (Hartwell et al., 1991), we calculated that the relationship between FR and tissue DTW of clams living in Lake Salvador and Lac des Allemands was: FR $\left(1 \mathrm{~h}^{-1}\right)=0.043 \times \mathrm{DTW}$ $(\mathrm{mg})^{0.56}$. The clams in these two lakes have, therefore, a FR of $2.061 \mathrm{~h}^{-1} \mathrm{~g}^{-1}$. Based on the relationship between filtration rate and clam size, and clam density and size obtained in this study, and assuming that clams actively graze $24 \mathrm{~h}$ a day, we estimate that it took clams about $1.5,1.5$, and 1.0 days to filter a water volume equivalent to Lake Cataouatche, Lake Salvador, and Lac des Allemands, respectively.

\section{Discussion}

The average Rangia density in these three lakes ranged from 63 to 157 individuals $\mathrm{m}^{-2}$ for all shells, and 57 to 107 Individuals $\mathrm{m}^{-2}$ for shells $>20 \mathrm{~mm}$. This density of the larger shells is lower than that observed in 1996/7 in Lakes Maurepas, Pontchartrain, and Borgne $(244 \pm 63,131 \pm 24$, and $60 \pm 31$ Individuals $\mathrm{m}^{-2}$, respectively $\left.(\mu \pm 1 \mathrm{SE})\right)$. The 
biomass in the three lakes ranged from 16.2 to $27.6 \mathrm{~g} \mathrm{~m}^{-2}$, which is less than the $35.4 \mathrm{~g} \mathrm{~m}^{-2}$ reported for Rangia in Lake Pontchartrain (Brammer et al., 2007), but comparable to some of the highest bivalve biomass densities reported (Dame \& Prins, 1998). We conclude that the population size of the Rangia population in these three lakes is significant, but less dense than in nearby Lake Pontchartrain.

\section{Differences among and within lakes}

Differences in the substrate (sediment) bulk properties seem to be the major determinant of relative abundance in these lakes. The highest clam densities among the three lakes were in Lake Salvador which had an average sand content of $4 \%$, compared to the higher amounts in Lakes Salvador and Catouatche, and the lowest densities were in softer substrates. The mortality of adult $R$. cuneata in silt-clay sediments in a transplantation experiment was higher, and the growth was lower, however, than for clams grown in sandy sediments (Tenore et al., 1968). This result may be because muddy sediments are more instable or that near-bottom turbidity generated by the action of bottom currents has a strong negative effect on their feeding efficiency, growth, and survival (Peddicord, 1977; Levinton, 2001). The high mass of live and dead clam shells in Lake Salvador may be related to the higher percentage of sand for appropriate settlement habitat for clam veligers and growth of juveniles.

The distribution of $R$. cuneata populations is due to factors that control spawning and survival of the larvae, but not adult physiology (Cain, 1973, 1975). Rangia spawn from March to May, and again from late summer into November (Fairbanks, 1963). Although gametogenesis is stimulated when temperatures reach $15^{\circ} \mathrm{C}$ or higher, spawning does not occur without a change in salinity (LaSalle \& de la Cruz, 1985). After spawning occurs, early larvae are not expected to survive unless the salinity is between 2 and $10 \mathrm{ppt}$, but salinity is no longer a critical factor after the larvae settle at the bottom (Cain 1973, 1975). In the three lakes we studied, however, the salinity was always lower than 1 psu (Table 1 ). Juvenile clams were mainly found in Lake Salvador (Fig. 2), where it is slightly brackish at times with salinities sometimes about 7.6 psu (Ren et al., 2009). There were no juvenile clams in Lake Cataouatche and only a few juveniles at one location in Lac des Allemands. Lake Cataouatche has a lower salinity than Lake Salvador, and an even lower salinity since July 2002, because of the Mississippi River water diverted through the Davis Pond Diversion (DPD) into the lake. The DPD project began releasing water at the end of July 2002 in controlled diversions of less than $40 \mathrm{~m}^{3} \mathrm{~s}^{-1}$ and outflows of as much as $80 \mathrm{~m}^{3} \mathrm{~s}^{-1}$ that occurred in January and February 2004 (Rabalais, 2005). About $8 \times 10^{8} \mathrm{~m}^{3}$ of Mississippi freshwater entered Lake Cataouatche before our survey. The salinity in Lac des Allemands was barely higher than zero, although small amounts of salt water may have entered the lake prior to our surveys. If salinity is a key factor influencing the occurrence of adult clams in Lac des Allemands, then the larvae in Lake Salvador must be the closest source of the larvae. In July 2005, we found that the clams in Lake Slavador were $<10 \mathrm{~mm}$ and that their density was as high as 2680 individuals $\mathrm{m}^{-2}$ at one location, but that there were no clam less than $29 \mathrm{~mm}$ anywhere in Lac des Allemands. A similar mode in the size distribution was found for Lake Cataouatche (Fig. 2), which suggests that recruitment into these two lakes had not recently occurred and that recruitment likely happened during the same time in these two lakes and, importantly, that recruitment was episodic, not continuous. A 29-mm clam would be about 1year old (Peddicord, 1977). The absence of clams smaller than $29 \mathrm{~mm}$, therefore, suggests that recruitment had not occurred for 12 months. This indicates that recruitment is irregular, at least in the year before our sampling.

A large scale factor that could influence recruitment in both lakes is coastal storms. It is possible that that a recruitment event occurred as a consequence of Tropical Storm Bill (TS Bill), which reached a peak wind speed of $95 \mathrm{~km} \mathrm{~h}^{-1} 1 \mathrm{~h}$ before making landfall in southwestern Terrebonne Parish 30 June, 2003. The highest wind force, and storm surge, was in the northwest quadrat of its path landward, which would have driven water northward along the north-south axis of Barataria Bay. TS Bill created a storm surge of about $1 \mathrm{~m}$ at the coast that propagated up Barataria Bay. This storm surge would have pushed water from Lake Salvador up northward into Lake Cataouatche and also into Bayou des Allemands, and into Lac des Allemands. A large coastal storm could have created a salinity change which larval recruitment requires 
and caused the difference in age structure observed in the two lakes and the coastal lake connecting them to a source of the larvae in Lake Salvador. We offer this explanation as a hypothesis, but not a conclusion, although we are without a reasonable alternative explanation that matches the field data with the results in the literature.

\section{Allometric relationships}

The power function between dry weight of both tissue and shell has been reported for a population of $R$. cuneata in Perdido Bay, Florida (Lane, 1986). Similar allometric relationships between the weight of tissue or shell and shell length (height) have been found in many bivalves, including gaper (horse) clams Tresus capax and T. nuttallii (Campbell \& Bourne, 2000), Astarte borealis (Zettler, 2002), blue mussel Mytilus edulis (Seed, 1976), scallops Annachlamys flabellate, Comptopallium radula, and Mimachlamys gloriosa (Lefort, 1994). The equations we developed for Rangia, however, are similar to those of Lane (1986) who conducted a starvation experiment on Rangia on shells ranging from 25 to $46 \mathrm{~mm}$. Although our observations predict about the same dry tissue weight (DTW) as Lane for a $30-\mathrm{mm}$ clam (126 mg compared to $132 \mathrm{mg}$ ), they also predict a much smaller weight for a $10-\mathrm{mm}$ shell $(4.7 \mathrm{mg}$ compared to $19.7 \mathrm{mg}$ ) and a much higher weight for a $50-\mathrm{mm}$ shell (585 mg compared to $321 \mathrm{mg}$ ). The reason for these differences is probably mostly due to the fact that the data used to generate Lane's equation, which was certainly suitable for his experiments, were for a narrower size range than ours $(2.0-48.7 \mathrm{~mm})$.

\section{Clearance times}

A comparison of the literature values for bivalve biomass and $\mathrm{CT}$ is shown in Fig. 6, together with a simple linear regression of the log transformed data for Rangia, oysters and mussels. The average estimated CT for the three lakes we studied ranged from 1.0 to 1.5 days (mean $=1.3$ days). These estimates of CT are relatively brief compared to that by oysters, mussels and clams in 11 coastal ecosystems reviewed by Dame \& Prins (1998; CT ranged from 0.7 to 1278 days). These are average CT we recognize that there will be variations in the $\mathrm{CT}$ ranging from days to months because of, for example, changes in food quantity and quality, salinity and temperature. The average CT in these three Louisiana coastal lakes, however, are short enough intervals to potentially influence phytoplankton composition and amounts, but only if the instantaneous phytoplankton growth rates are less net losses, e.g., from dilution, death, or predation. The freshwater turnover times in these three lakes are 10 to 100 times larger than the CT, which means that the potential for the bivalves to significantly influence the water column plankton community is a possibility if the in situ losses are greater than the growth rates. The instantaneous phytoplankton growth rate is certainly high in these systems because Barataria Bay is sometimes a eutrophic (Lake Cataouatche and Lake Salvador) or hyper-eutrophic (Lac des Allemands) system whose Chl- $a$ concentration may exceed $200 \mu \mathrm{g}^{-1}$ and include harmful and toxic algal blooms (Table 1; Rabalais, 2005). A daily phytoplankton doubling rate of 1 , which is realistic when abundant nutrients are available, would be sufficient to compensate for an average clearance time of 1.3 in the three lakes. The Rangia population in Lake Pontchartrain is even larger than in these three lakes. The average Chl- $a$ concentration in the middle of Lake Pontchartrain is $<10 \mu \mathrm{g} \mathrm{Chl}-a 1^{-1}$, and the turnover of water is $1.78 \%$ day $^{-1}$ (Turner et al., 2004), and so the potential influence of Rangia clearance times are even higher there than in the three lakes we studied. The occasional blooms in Lake Pontchtrain (Dortch et al., 1999) are evidence that the CT by bivalves is too low to always control phytoplankton population densities. Thus, we do not presume to conclude that the filtration capacity of Rangia exceeds the growth rate of phytoplankton, or individual species, throughout the year, but we do anticipate that the clearance time is sufficiently influential at some times more than others, e.g., (1) during lows in nutrient loading; (2) immediately after relatively high discharge events when lake water is quickly diluted and the lake's planktonic chemostat is 'reset' to begin a new growth phase, or, (3) in different regions of a water body, e.g., in shallow zones where there are regional peaks in the biomass. Bivalves consume, consolidate, and transform particles as feces, pseudofeces, and in the bioturbation of sediments and the filtration of suspended matter by Rangia and other bivalves varies with suspended matter concentration or may 


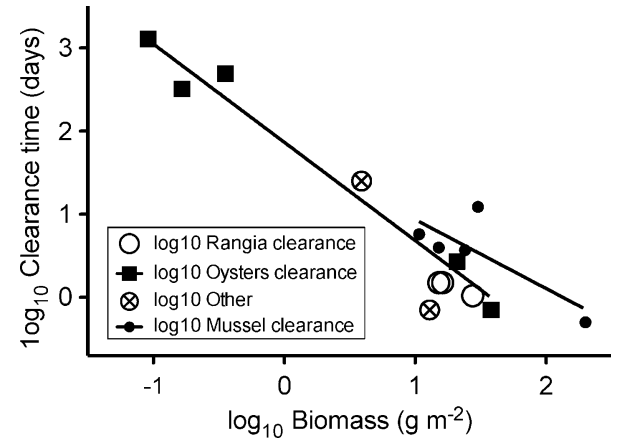

Fig. 6 The relationship between the biomass of bivalves $\left(\mathrm{g} \mathrm{m}^{-2}\right)$ and the clearance time (days) for the water column they are found in. The data for Rangia cuneata are for the three lakes examined in this study. Data for two clam-dominated (Mercenaria mercenaria or Potamocorbula amurensis), five oyster-dominated (Crassostrea virginica) and four musseldominated (Mytilus edulis) coastal systems are in Dame \& Prins (1998). Data for an additional mussel-dominated system (Baltic Sea) is from Haamer \& Rodhe (2000). Data for the total shell weight of a Corbicula fluminea dominated system (Potomac River, Phelps, 1994) were converted to dry weight of tissue to assuming $5.6 \%$ dry weight of wet weight (Riccardi, 1998). The two straight lines are a linear regression of the transformed data and are for mussels (small closed circle) and oysters (closed square), but not for the three other taxonomically distinct other bivalves (circle with an ' $x$ ') and Rangia

be processed as pseudofeces (Widdows et al., 1979; Vaughn \& Hakenkamp, 2001). An argument could be made, therefore, that the potential effects of Rangia filtration could be diminished by a rise in suspended sediment concentration (e.g., from dredging or river diversions) and result in a compensatory re-allocation of energy consumed toward pseudofecal production, something that Peddicord (1977) concluded happens in the James River, Virginia. In the same way, Rangia may, or may not, significantly reduce bacteria concentrations which they are capable of consuming (Cloern \& Alpine, 1991; Werner \& Hollibaugh, 1993; Silverman et al., 1997).

\section{Conclusions}

The Rangia populations in the northern GOM estuaries have equivalent or higher biomass and filtering capacities as bivalves in other shallow water (Fig., 6). Their presence in Louisiana estuaries meets the criteria Officer et al. (1982) outlined for bivalves to have a controlling influence on plankton communities at some times, but not always. The presence of
Rangia in sufficient quantities is predicted to have a cascading series of consequences for the aquatic ecosystem, i.e., a reduction in particle density that improves light penetration, which may enhance the growth of submerged aquatics, which then provides habitat for dependent organisms. The hard surface may become a substrate for epiphyte grazers (Peterson \& Heck, 1999, 2001), its flesh is consumed by fish and fowl, and the accumulation of shells stabilizes sediments and shorelines. These small, but numerous, individual Rangia can be a critical part of the ecological processes in shallow water systems of the GOM.

Acknowledgments This work was supported by the NOAA Coastal Ocean Program MULTISTRESS Awards No. NA16O P2671 and NA16OP2670. We thank E. Swenson for making estimates of the water volume in the three lakes.

\section{References}

Abadie, S. W. \& M. A. Poirrier, 2000. Increased density of large Rangia clams in Lake Pontchartrain after the cessation of shell dredging. Journal of Shellfish Research 19: 481-485.

Andrews, L. S. \& R. M. Grodner, 1995. Muddy flavor and acceptability of fresh iced-stored and value added Louisiana Rangia clam. Journal of Food Quality 18: 445-453.

Ball, B., R. Raine \& D. Douglas, 1997. Phytoplankton and particulate matter in Carlingford Lough, Ireland: an assessment of food availability and the impact of bivalve culture. Estuaries 20: 430-440.

Brammer, A. J., Z. Rodriguez del Rey, E. A. Spalding \& M. A. Poirrier, 2007. Effects of the 1997 Bonnet Carré spillway opening on infaunal macroinvertebrates in Lake Pontchartrain, Louisiana. Journal of Coastal Research 23: 1292-1303.

Cain, T. D., 1973. Combined effects of temperature and salinity on embryos and larvae of clam Rangia cuneata. Marine Biology 21: 1-6.

Cain, T. D., 1975. Reproduction and recruitment of brackish water clam Rangia cuneata in James River, Virginia. Fishery Bulletin 73: 412-430.

Campbell, A. \& N. Bourne, 2000. Population biology of gaper (horse) clams, Tresus capax and T. nuttallii, in southern British Columbia, Canada. Journal of Shellfish Research 19: 933-942.

Caraco, N. F., J. J. Cole, P. A. Raymond, D. L. Strayer, M. L. Pace, S. E. G. Findlay \& D. T. Fischer, 1997. Zebra mussel invasion in a large, turbid river: phytoplankton response to increased grazing. Ecology 78: 588-602.

Cloern, J. \& A. Alpine, 1991. Potamocorbula amurensis, a recently introduced Asian clam, has had dramatic effects on the phytoplankton biomass and production in northern San Francisco Bay. Journal of Shellfish Research 10: 258-259. 
Cohen, R. R. H., P. V. Dresler, E. J. P. Phillips \& R. L. Cory, 1984. The effect of the Asiatic clam, Corbicula fluminea, on the phytoplankton of the Potomac River, Maryland. Limnology and Oceanography 29: 170-180.

Coughlan, J., 1969. The estimation of filtering rate from clearance of suspensions. Marine Biology 2: 356-358.

Dame, R. F. \& T. C. Prins, 1998. Bivalve carrying capacity in coastal ecosystems. Aquatic Ecology 31: 409-421.

Dortch, Q., M. L. Parson, N. N. Rabalais \& R. E. Turner, 1999. What is the threat of harmful algal blooms in Louisiana coastal waters? In Rozas, L. P., J. A. Nyman, C. E. Proffitt, N. N. Rabalais, D. J. Reed \& R. E. Turner (eds), Recent Research in Coastal Louisiana. Louisiana Sea Grant Publication, Baton Rouge.

Ebersole, E. L. \& V. S. Kennedy, 1994. Size selection of Atlantic Rangia clams, Rangia cuneata, by blue crabs, Callinectes sapidus. Estuaries 17: 668-673.

Fairbanks, L. D., 1963. Biodemographic studies on the clam Rangia cuneata Gray. Tulane Studies on Zoology 10: 347.

Francis, J. C. \& M. A. Poirrier, 1999. Recent trends in water clarity of Lake Pontchartrain. Gulf Coast Research Reports 11: 1-5.

Gaston, G. R., C. M. Cleveland, S. S. Brown \& C. F. Rakocinski, 1997. Benthic-pelagic coupling in northern Gulf of Mexico estuaries: do benthos feed directly on phytoplankton? Gulf Coast Research Reports 9: 231-237.

Haamer, J. \& J. Rodhe, 2000. Mussel Mytilus edulis (L.) filtering of the Baltic Sea outflow through the Öresund-an example of a natural, large-scale ecosystem restoration. Journal of Shellfish Research 19: 413-421.

Hartwell, J. I., D. A. Wright, R. Takacs \& C. H. Hocutt, 1991. Relative respiration and feeding rates of oyster and brackish water clam in variously contaminated waters. Marine Pollution Bulletin 22: 191-197.

Hoese, H. D., 1973. Abundance of the low salinity clam, Rangia cuneata in southwestern Louisiana. Proceedings of National Shellfisheries Association 63: 99-106.

Hopkins, S. H. \& J. D. Andrews, 1970. Rangia cuneata on the East Coast: thousand mile range extension, or resurgence? Science 167: 868-869.

Kang, C. K., M. S. Park, P. Y. Lee, W. J. Choi \& W. C. Lee, 2000. Seasonal variations in condition, reproductive activity, and biochemical composition of the Pacific oyster, Crassostrea gigas (Thunberg), in suspended culture in two coastal bays of Korea. Journal of Shellfish Research 19: 771-778.

Kelaher, B. P., J. S. Levinton, J. Oomen, B. J. Allen \& W. H. Wong, 2003. Changes in benthos following the clean up of a severely metal-polluted cove in the Hudson River Estuary: environmental restoration or ecological disturbance? Estuaries 26: 1505-1516.

Krumbein, W. C. \& F. J. Pettijohn, 1938. Manual of Sedimentary Petrography. Appleton-Century-Crofts, Inc., New York.

Lane, J. M., 1986. Allometric and biochemical studies on starved and unstarved clams, Rangia cuneata (Sowerby, 1831). Journal of Experimental Marine Biology and Ecology 95: 131-143.

LaSalle, M. W. \& A. A. de la Cruz, 1985. Species Profiles: Life Histories and Environmental Requirements of Coastal Fishes and Invertebrates (Gulf of Mexico)—Common
Rangia. Biological Reports 82 (11.31). Research and Development Branch of the US Fish and Wildlife Service, Washington.

Lefort, Y., 1994. Growth and mortality of the tropical scallops-Annachlamys flabellata (Bernardi), Comptopallium radula (Linne) and Mimachlamys gloriosa (Reeve) in southwest lagoon of New Caledonia. Journal of Shellfish Research 13: 539-546.

Levinton, J. S., 2001. Marine Biology: Function, Biodiversity, Ecology. Oxford University Press, New York.

Officer, C. B., T. J. Smayda \& R. Mann, 1982. Benthic filter feeding: a natural eutrophication control. Marine Ecology Progress Series 9: 203-210.

Peddicord, R. K., 1977. Salinity and substratum effects on condition index of the bivalve Rangia cuneata. Marine Biology 39: 351-360.

Peterson, B. J. \& K. L. J. Heck, 1999. The potential for suspension feeding bivalves to increase seagrass productivity. Journal of Experimental Marine Biology and Ecology 240: 37-52.

Peterson, B. J. \& K. L. J. Heck, 2001. An experimental test of the mechanism by which suspension feeding bivalves elevate seagrass productivity. Marine Ecology Progress Series 218: 115-125.

Phelps, H. L., 1994. The Asiatic clam (Corbicula fluminea) invasion and system-level ecological change in the Potomac River estuary near Washington, DC. Estuaries 17: 614-621.

Pomeroy, L. R., C. F. D’Elia \& L. C. Schaffner, 2006. Limits to top-down control of phytoplankton by oysters in Chesapeake Bay. Marine Ecology Progress Series 325: 301-309.

Pomeroy, L. R., C. F. D’Elia \& L. C. Schaffner, 2007. Topdown control of phytoplankton by oysters in Chesapeake Bay, USA: Reply to Newell et al. Marine Ecology Progress Series 341: 299-301.

Rabalais, N. N., 2005. Consequences of Mississippi River Diversion for Louisiana Coastal Restoration. National Wetlands Newsletter: 21-24.

Ren, R., N. N. Rabalais, R. E. Turner, W. Morrison \& W. Mendenhall, 2009. Nutrient limitation on phytoplankton growth in the Upper Barataria Basin, Louisiana: Microcosm bioassays. Estuaries and Coasts 32: 958-974.

Seed, R., 1976. Ecology. In Bayne, B. L. (ed.), Marine Mussels: Their ecology and physiology. Cambridge University Press, London.

Sikora, W. B. \& J. P. Sikora, 1981. Environmental Effects of Hydraulic Dredging for Clam Shells in Lake Pontchartrain, Louisiana, Rep No LSU-CEL-81-18. Coastal Ecology Laboratory, Center for Wetland Resources, Baton Rouge.

Silverman, H., S. J. Nichols, J. S. Cheery, E. Achberger, J. W. Lynn \& T. H. Dietz, 1997. Clearance of laboratory-cultured bacteria by freshwater bivalves: differences between lentic and lotic unionids. Canadian Journal of Zoology 75: 1857-1866.

Tenore, K. R., D. B. Horton \& T. W. Duke, 1968. Effects of bottom substrate on the brackish water bivalve Rangia cuneata. Chesapeake Science 9: 238-248.

Turner, R. E., 2001. Of manatees, mangroves, and the Mississippi River: is there an estuarine signature for the Gulf of Mexico? Estuaries 24: 139-150. 
Turner, R. E., Q. Dortch \& N. N. Rabalais, 2004. Inorganic nitrogen transformations at high loading rates in an oligohaline estuary. Biogeochemistry 68: 411-423.

Vaughn, C. C. \& C. C. Hakenkamp, 2001. The functional role of burrowing bivalves in freshwater ecosystems. Freshwater Biology 46: 1431-1446.

Verween, A., F. Kerckhof, M. Vincx \& S. Degraer, 2006. First European record of the invasive brackish water clam Rangia cuneata (GB Sowerby I, 1831) (Mollusca: Bivalvia). Aquatic Invasions 1: 198-203.

Wakida-Kusuoki, A. T. \& C. L. MacKenzie Jr., 2004. Rangia and marsh clams, Rangia cuneata, $R$. flexuosa, and Polymesoda caroliniana, in Eastern México: distribution, biology and ecology, and historical fisheries. Marine Fisheries Review 66: 13-20.
Werner, I. \& J. T. Hollibaugh, 1993. Potamocorbula amurensis: comparison of clearance rates and assimilation efficiencies for phytoplankton and bacterioplankton. Limnology and Oceanography 38: 949-964.

Widdows, J., P. Fieth \& C. M. Worrall, 1979. Relationships between seston, available food and feeding activity in the common mussel Mytilus edulis. Marine Biology 50: 195207.

Zar, J. H., 1996. Biostatistical Analysis. Prentice Hall, Inc., Upper Saddle River.

Zettler, M. L., 2002. Ecological and morphological features of the bivavle Astarte borealis (Schumacher, 1817) in the Baltic Sea near its geographical range. Journal of Shellfish Research 21: 33-40. 